\title{
The evolution of online education for sports coaches: A tennis perspective
}

\author{
Richard Sackey-Addo (GBR) and Javier Pérez Camarero (ESP) \\ ITF Coaching and Sport Science Review 2016; 68 (24): 31-33
}

RÉSUMÉ

This article looks at how modern coach education has progressed with the development of more resources and online learning platforms dedicated to informal and distance-learning based courses for coaches and what the effects of this means for the future of coach education courses for coaches and tutors.

\author{
Mots clés: distance-learning, \\ coach education, visual learning \\ Article reçu: 11 January 2015 \\ Article accepté: 15 February \\ 2016 \\ Auteur correspondant: Richard \\ Sackey-Addo \\ Email: coaching@itftennis.com
}

\section{INTRODUCTION}

The transition in the processes and methodology of knowledge acquisition for the modern tennis coach now gives rise to an increasing body of research that is focused on gaining a better understanding of the most effective ways for coaches develop their craft and learn how to coach (Cushion et al., 2010). It has been stated that the three most fundamental questions to be considered with regard to the development and assessment of coaches are; what knowledge should be taught to novice coaches? What is the optimal method for teaching this knowledge? And how should assessing be carried out in order to optimally encourage the continuation of learning throughout a coaches' career? (Abraham, Collins, 1998). The continual efforts from National Tennis Associations and the introduction of successful ITF participation initiatives, such as the Junior Tennis Initiative and Play and Stay, and the increasing high standards at the elite level of the game make it more necessary than ever for coaches to be suitably qualified, competent and have necessary opportunities for continued professional development available to them.

The effectiveness of coach education programmes has been identified as a key factor in the development of quality coaches with recent emphasis being placed on strategic appraisals of coaching and coach education which have contributed to the emergence of national benchmarks/standards for practice in sub-elite coaching across National Governing Bodies (NGB's) and International Federations (IF's) (Knowles et. Al 2005).

\section{ONLINE LEARNING PLATFORMS}

The evolution of technology and the ease in which information can be sought has been taken advantage of by IF's and NGB's. "Traditional" eLearning modules comprise various formats, such as Computer-Based Training (CBT), Web-Based Training (WBT), Web- Lectures (WL) and Web-Meetings, sometimes in stand-alone versions and sometimes in combinations of these (Mester, Wigger, 2011). As with regards to online courses and education platforms, from the perspective of a coach, everything is easy to find and coaching information is at your fingertips. You can take the right information out easily and at the right time (Elderton, 2013). However, it has been suggested to use a wide range of training methods, from the traditional lecture format through to video, online learning and, of course, actual teaching sessions during which your students will be responsible for players under your supervision (Pestre, 2013).

In the case of the Royal Federación Española de Tenis (RFET) it was identified that one of the main reasons that coaches do not attend educational events is the lack of time and economic resources. Therefore, the Federation introduced a number of online educational plans that have proven to be very successful, both from the point of view of the feedback provided by the coaches as well as the number of people enrolled.

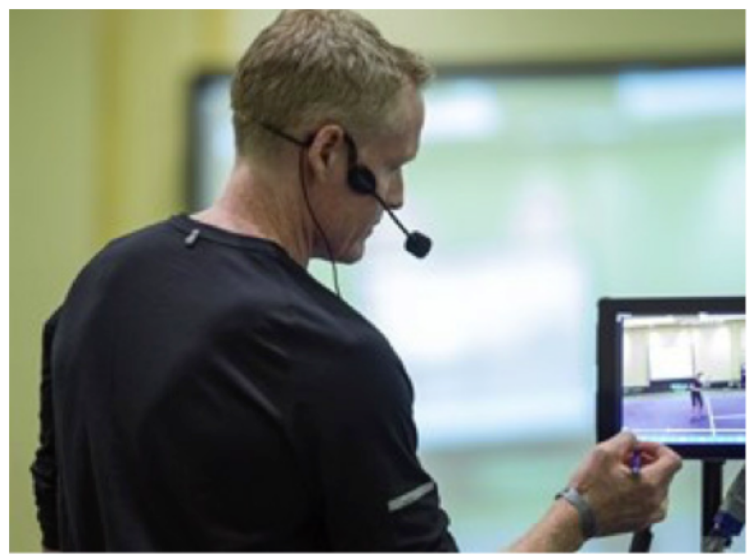

Practical applications

- In the case of the Royal Federación Española de Tenis (RFET) it was identified that one of the main reasons that coaches do not attend educational events is the lack of time and economic resources. Therefore, the Federation introduced a number of online educational plans that have proven to be very successful, both from the point of view of the feedback provided by the coaches as well as the number of people enrolled.

- Educational technologies available today in conjunction with the advances of the internet, have had a tremendous impact on the availability and ease of access to information for coaches. Learning resources such as ITF Tennis iCoach serve as an example of where coaches are able to access up-to-date and continuous education resources with ease, thus allowing 
for more continuous education during their career should the coach choose (Over \& Sharp, 2008). Whatever is done to make education more attractive, functional and practical for coaches will ultimately serve to have a positive effect on the quality of coaches worldwide.

Benefits

Some studies have concluded that there are no significant differences in results between online training and classroom (Barry, Runyan, 1995). However, the argument can be stated that through online educational/CPD platforms, coaches can now make better use of their time by being able to draw on these resources at a time and place that is best appropriate to them, a key factor to consider for tennis coaches who may spend most of their time on-court or travelling with players. Thanks to online educational platforms, coaches do not need to have to book a weekend or several days off or deal with problems of cancellation of courses that can be attributed to classroom environments.

Another of the important advantages offered from online training is the opportunity to obtain information repeatedly. We can see a video conference or exercise, pause, rewind and replay as many times as you want and tutors can also take advantage of these online resources for teaching students when in a classroom.

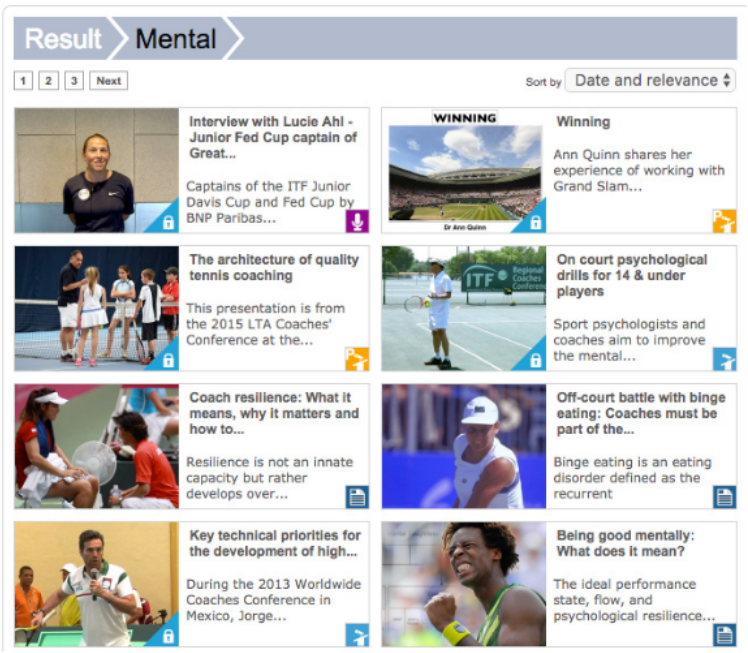

Online education tips

The following can be considered when choosing an appropriate online education course:

- Is there an online course community for discussions, blogs etc. - Opportunities to network and share discussion topics with other likeminded professionals can be advantageous in allowing interaction between coaches and experts with different experiences and backgrounds and learning from others and are the online equivalent of discussions in a classroom environment.

- How long is the course/individual units - Often for coaches, it is not possible to be able to balance several hours, weeks or even months at a time working through content, due to this shorter courses requiring less demands on time can be recommended.

- Is the course endorsed by a reputable organisation/governing body - As is becoming more common, more national and international sports federations are providing and endorsing courses held by external companies. -Where can the course content be accessed - In an era where laptops, tablets and smartphones are common items of technology to have amongst most coaches it is important that coaches can access content anywhere and anytime to a variety of different devices.

- Will the certificate of attendance or qualification at the completion of the course be recognised - The certificate of attendance or qualification gained at the end of the course should ensure that the competencies covered will enhance your continued professional development and career opportunities.

\section{CONCLUSION}

It is important to insist on utilisation of good quality resources and material obtained through online education platforms as the benefits apply not just to tennis coaches but to course tutors who can also make use of, in a classroom setting, using a tablet or laptop to display demonstrative training content so that coaches are able to learn through more direct, visual and time-efficient means.

\section{REFERENCES}

Abraham, A., \& Collins, D. (1998). Examining and extending research in coach development. Quest, 50(1), 5979.https://doi.org/10.1080/00336297.1998.1048 4264

Barry, M. \& Runyan, G. (1995). A review of distance learning studies in the U.S. military. The American Journal of Distance Education, 9

(3).https://doi.org/10.1080/08923649509526896

Cushion, C., Nelson, L., Armour, K., Lyle, J., Jones, R., Sandford, R., \& O'Callaghan, C. (2010). Coach learning and development: A review of literature. Leeds: Sports Coach UK.

Elderton, W. (2013). Principles of modern coaching methodology: An evolution, 60, 8-9.

Felder, R. M. \& Silverman, L.K. (1988) "Learning and Teaching Styles in Engineering Education". Engr. Education, 78(7), 674-681. Mester, J. \& Wigger, U. (2011).Online resources for coaches education:Motivation for applied Intellectual Capital Management in tennis, 54, 19-20.

Over, S. and Sharp, B. (2008). Information Technology in tennis. ITF Coaching and Sport Science Review. 15 (45): 24-25.

Oxford, R. L., Hollaway, M. E. \& Horton-Murillo, D. (1992). Language learning styles: Research and practical considerations for teaching in the multicultural tertiary ESL/EFL classroom. Recuperado en marzo de 2010, de www.ukessays.com/essays/englishidioma/aprendizaje-estilos.

Php.https://doi.org/10.1016/0346251X(92)90057-A

Pestre, B. (2013). Teacher education on court, 60,2425.https://doi.org/10.12968/prtu.2013.1.25.60

SÉLECTION DE CONTENU DU SITE ITF TENNIS ICOACH (CLIQUEZ)

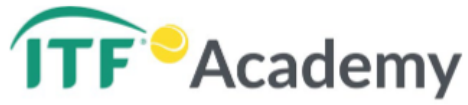

\author{
Droits d'auteur (c) Richard Sackey-Addo and Javier Pérez \\ Camarero 2016
}

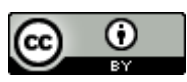

Ce texte est protégé par une licence Creative Commons 4.0 
Vous êtes autorisé à Partager - copier, distribuer et communiquer le matériel par tous moyens et sous tous formats - et Adapter le document - remixer, transformer et créer à partir du matériel pour toute utilisation, y compris commerciale, tant qu'il remplit la condition de:

Attribution: Vous devez créditer l'CEuvre, intégrer un lien vers la licence et indiquer si des modifications ont été effectuées à l'Oeuvre. Vous devez indiquer ces informations par tous les moyens raisonnables, sans toutefois suggérer que l'Offrant vous soutient ou soutient la façon dont vous avez utilisé son Oeuvre. Résumé de la licence - Texte intégral de la licence 